\title{
Indeksasi Jurnal di Lingkungan Universitas Lancang Kuning
}

\author{
Nining Sudiar ${ }^{1}$; Hadira Latiar ${ }^{1}$ \\ ${ }^{1}$ Program Studi Ilmu Perpustakaan, Fakultas Ilmu Budaya, Universitas Lancang Kuning \\ "Korespondensi: sudiar.nining@ gmail.com
}

\begin{abstract}
This study aims to analyze the development of journal indexation in Lancang Kuning University by calculating the type of indexing institutions and counting the number of indexations in each journal. The research method used is quantitative descriptive using literature approach through searching the journal URL Unilak. The results showed there were 38 types of indexers with 143 indexers in 16 journals. The top five ranks indexing institutions, first, Crossref and Google Scholar, namely 16 journals or 18.83\%, second Garuda 11 journals or $7.69 \%$, the third is OCLC WorldCat as many as 10 journals or 6.99\%, the forth is the Academic Search Engine Bielefels (BASE) namely 9 journals or 6.29\% and the fifth is Science and Technology Index (Sinta) with a total of 8 journals or 5, 59\%. It can be concluded that indexing institutions most owned by Unilak journals are lowreputation indexing institutions namely $95.11 \%$, medium-sized indexing institutions $4.89 \%$ and do not yet have high-ranking indexing institutions such as Scopus and Thomson.
\end{abstract}

Keywords: journal indexing; indexation; journal; lancang kuning university

\begin{abstract}
Abstrak
Penelitian ini bertujuan untuk menganalisis perkembangan indeksasi jurnal yang ada di Universitas Lancang Kuning dengan cara menghitung jenis lembaga pengindeks dan menghitung jumlah indeksasi yang pada setiap jurnal. Metode penelitian yang digunakan adalah deskriptif kuantitatif dengan pendekatan kepustakaan melalui penelusuran pada URL jurnal Unilak. Hasil penelitian menunjukan bahwa ada 38 jenis pengindeks dengan jumlah 143 lembaga pengindeks yang terdapat pada 16 jurnal. Lima peringkat lembaga pengindeks terbanyak, pertama, Crossref dan Google Scholar yaitu 16 jurnal atau 18,83\%, kedua Garuda sebanyak 11 jurnal atau 7,69\%, ketiga OCLC WorldCat sebanyak 10 jurnal atau 6,99 \%, keempat ada pada Bielefels Academic Search Engine (BASE) yaitu 9 jurnal atau 6,29 \% dan yang kelima ada pada Science and Technology Index (Sinta) dengan jumlah 8 jurnal atau 5,59\%. Dapat disimpulkan bahwa lembaga pengindeks yang paling banyak dimiliki jurnal Unilak adalah lembaga pengindeks bereputasi rendah yaitu $95,11 \%$, lembaga pengindeks bereputasi sedang 4,89\% dan belum memiliki lembaga pengindeks bereputasi tinggi seperti Scopus dan Thomson.
\end{abstract}

Kata Kunci: indeksasi jurnal; indeksi; jurnal, universitas lancang kuning

\section{PENDAHULUAN}

Jurnal adalah salah satu bentuk publikasi ilmiah, jurnal ilmiah biasanya diterbitkan sebagai cara untuk atau media untuk menyebarluaskan hasil-hasil penelitian baik dalam disiplin atau subdispilin ilmu tertentu. Dalam Kamus Kepustakawan menjelaskan bahwa jurnal sebenarnya merupakan publikasi ilmiah yang memuat informasi tentang hasil kegiatan dalam bidang ilmu pengetahuan dan teknologi minimal harus mencakup kumpulan/ kumulasi pengetahuan baru, pengamatan empiris, dan pengembangan gagasan/ usulan (Hs, 2009). Jurnal (journal) adalah sarana komunikasi untuk melaporkan sebuah peristiwa atau gagasan kepada public secara berkala, biasanya dalam bentuk majalah (Hariyanto, 2016). Literature lain mendefinisikan jurnal sebagai majalah khusus (Janet Stevenson dan Collin, 2006). Sehingga dapat disimpulkan bahwa jurnal adalah hasil representasi dari ilmu pengetahuan baru yang dilaksanakan secara empiris dan biasanya merupakan gagasan yang kekinian atau terbaru. Dengan adanya perkembangan teknologi informasi maka muncullah jurnal elektronik (electronic journals) atau disebut juga dengan online journal. Menurut Jamaluddin e-journal adalah jurnal yang segala aspek (penyiapan, review, penerbitan, dan penyebaran) dilakukan secara elektronik (Jamaluddin 2015). Artinya bahwa jurnal elektronik merupakan versi digital dari jurnal tercetak, atau jurnal seperti dalam bentuk publikasi elektronik tanpa versi tercetaknya, yang tersedia melalui email, web atau akses internet. Jurnal 
elektronik tersebut dikelola secara daring menggunakan system OJS (Online Journals System). OJS merupakan sistem manajemen jurnal dan penerbitan online yang telah dikembangkan oleh Public Knowledge Project melalui upaya yang didanai pemerintah federal untuk memperluas dan meningkatkan akses pada penelitian (Indriyanti, 2010). Menurut Wicaksono dalam penelitiannya, bahwa jurnal elektronik ditanggapi positif oleh mahasiswa di Jakarta (Wicaksono, 2018). Hal ini menunjukkan bahwa jurnal elektronik telah menjadi kebutuhan bagi para mahasiswa.

Seiring dengan adanya Permenristek Dikti Republik Indonesia Nomor 9 Tahun 2018 tentang Akreditasi Jurnal Ilmiah (Sandi, 2018). Peraturan ini secara tidak langsung menuntut setiap jurnal yang ada di Indonesia untuk meningkatkan mutu jurnal ilmiah yang dikelolanya melalui akreditasi jurnal meliputi, kewajaran penyaringan, kelayakan naskah (relevansi), dan ketepatan waktu penerbitan. Salah satu persyaratan yang wajib dipenuhi dalam akreditasi jurnal yaitu adanya indeksasi jurnal. Indeksasi adalah pendaftaran jurnal pada lembaga pengindeks bereputasi (Penyusun et al. 2017). Indeksasi jurnal selain berfungsi sebagai proses desiminasi jurnal secara luas, namun juga bermanfaat sebagai sarana promosi kepada khalayak umum, serta akan memudahkan proses sitasi secara global karena terindeks diberbagai database. Indeksasi jurnal bertujuan untuk mendeseminasikan atau menyebarluaskan jurnal yang terbit, dan menunjukkan prestasi sehingga dapat dikenal secara luas (Sahrudin, 2019). Dengan menyebarluaskan jurnal diharapkan akses ke sumber informasi ilmiah menjadi semakin mudah. Akan tetapi menurut Nashihudin dan Rahayu aksesibilitas sumberi informasi di lembaga riset dan perpustakaan hendaknya memperhatikan kebijakan yang menyangkut batasan-batasan akses, terutama akses konten informasi ilmiah full text pada database, agar tidak melanggar hak cipta (Nashihudin \& Rahayu, 2010).

Univeristas Lancang Kuning adalah salah satu Perguruan Tinggi Swasta (PTS) yang ada di Pekanbaru Provinsi Riau, memiliki jurnal ilmiah yang dikelola langsung oleh unit kerja seperti program studi, fakultas dan LPPM Universitas. Hingga saat ini Unilak telah memiliki 29 Jurnal ilmiah baik jurnal yang berfokus pada hasil penelitian maupun dari hasil pengabdian kepada masyarakat. Pada tabel 1 berikut pertumbuhan jurnal ilmiah yang ada di lingkungan Universitas Lancang Kuning.

Tabel 1

Daftar Pertumbuhan Jurnal di Lingkungan Unilak dalam Tahun

\begin{tabular}{ccc}
\hline No & Tahun & Jumlah \\
\hline 1 & 2004 & 1 \\
2 & 2005 & 1 \\
3 & 2007 & 1 \\
4 & 2014 & 5 \\
5 & 2015 & 6 \\
6 & 2016 & 3 \\
7 & 2017 & 2 \\
8 & 2018 & - \\
9 & 2019 & 10 \\
\hline \multicolumn{2}{r}{ Sumber: https:/journal unilak acid/ }
\end{tabular}

Sumber: https://journal.unilak.ac.id/

Dari Tabel 1 dapat dilihat perkembangan jurnal ilmiah dari tahun ketahun, dari tahun 2004 hingga tahun 2005 Unilak hanya memiliki dua jurnal yaitu Jurnal Ilmu Budaya dan Jurnal Ilmu Pertanian, tahun 2007 penambahan satu jurnal yaitu Jurnal Teknik, tahun 2014 bertambah lima jurnal yaitu Jurnal Bio Lectura, Lectura: Jurnal Pendidikan, ELT- Lectura, Jurnal Pustaka Budaya, Jurnal Arsitektur: Arsitektur Melayu dan Lingkungan, tahun 2015 penambahan enam jurnal yaitu Wahana Foresta: Jurnal Kehutanan, Jurnal Agribisnis, Digital Zone, Jurnal Ilmiah Ekonomi dan Bisnis dan SIKLUS: Jurnal Teknik Sipil, tahun 2016 penambahan tiga jurnal yaitu Jurnal Niara, 
Jurnal Hukum Respublica dan SainETIn, tahun 2017 penambahan dua jurnal Dinamisia: Jurnal Pengabdian Kepada Masyarakat dan PAUD Lectura: Jurnal Pendidikan Anak Usia Dini, dan tahun 2019 terjadi pelonjakkan yang sangat tinggi dari tahun sebelumnya yaitu penambahan 10 jurnal yang terdiri dari jurnal Gagasan Hukum, ELSYA: Journal of English Language Studies, UTAMAX: Journal of Ultimate Research and Trends in Education, Seminar Nasional Pengabdian Kepada Masyarakat Unilak, JOELS (Journal of Election and Leadership), IJHas: International Journal on Humanity and Society, IJETECH: International Jurnal of Environtment and Technology dan REiLA: Journal of Research and Innovation in Languange.

Penelitian terkait indeksasi jurnal ilmiah pernah dilakukan oleh Rahmawati dengan judul Analisis Indeksasi Jurnal Ilmiah Bidang Pertanian Indonesia di DOAJ (Rahmawati, 2018). Penelitian ini bertujuan untuk mendeskripsikan bagaimana indeksasi jurnal ilmiah bidang pertanian yeng terbit di Indonesia pada DOAJ. Metode penelitian yang digunakan adalah penelitian kepustakaan dengan melakukan penelusuran dokumen-dokumen secara online. Hasil penelitian menunjukan bahwa sebanyak 19 jurnal mengenakan biaya penerbitan kepada penulis, berdasarkan penerbit, IPB merupakan penerbit jurnal ilmiah bidang pertanian terbanyak dibandingkan institusi Indonesia terdaftar pertama kali di DOAJ pada tahun 2013, yaitu Jurnal Manajemen \& Agribisinis yang diterbitkan oleh IPB, sebanyak 14 jurnal yang menggunakan proses peer review. Sedangkan berdasarkan lisensi terbanyak yang digunakan adalah CC-BY.

Penelitian kedua oleh Andrea Marchitelli yang berjudul Meningkatkan Kualitas Editorial Jurnal yang terindeks di Dalam DOAJ: Analisis Data (Andrea Marchitelli dan Galimberti, 2017). DOAJ memperluas dan memperbarui kriteria dan proses evaluasi jurnal yang pada akhirnya menghapus sejumlah besar jurnal. Penelitian ini meneliti hasil dari baru dan kemampuannya untuk meningkatkan kualitas direktori dan keandalan informasi yang terkandung di dalamnya. Alasan dikeluarkannya jurnal dari DOAJ adalah penerbit gagal menyelesaikan aplikasi tepat waktu, telah berhentinya publikasi, masalah etika, bukan akses terbuka, dan beberapa alasan lainnya. Penelitian ini menunjukkan bahwa jurnal yang dihapus termasuk dalam daftar Beall, jurnal yang diindeks dalam DOAJ termasuk dalam Scopus atau JCR. Analisis ini menunjukkan bahwa, adanya peningkatan yang nyata dari indeks jurnal yang diindeks dalam DOAJ berkat kriteria penerimaan yang baru, untuk proses penyaringan dan pengelompokannya.

Penelitian ketiga oleh Sri Junandi dengan judul Pengelolaan Jurnal Elektronika Bidang Perpustakaan Menuju Jurnal Terakreditasi (Junandi, 2018). Tulisan ini mendeskripsikan bagaimana pengelolaan jurnal ilmiah dalam rangka mencapai jurnal ilmiah terakreditasi nasional memerlukan Sistem Manajemen dan Pengelolaan Jurnal yang efektif dan efisien. Sistem Manajemen dan Pengelolaan Jurnal ini harus mengacu kepada instrumen-intrumen dan kriteriakriteria yang disyaratkan oleh akreditasi jurnal nasional dan lembaga pengindeks internasional. Pengelola Berkala Ilmu Perpustakaan dan Informasi telah menerapkan sebagian besar instrumen dan kriteria yang ditetapkan sesuai Peraturan Direktur Jenderal Dikti Nomor 1 Tahun 2014 tentang Pedoman Akreditasi Terbitan Berkala Ilmiah. Selain itu pengelola BIP secara aktif mengikuti perkembangan terkait pengelolaan jurnal dengan mengikuti workshop, pelatihan, pendampingan, hibah tata kelola jurnal elektronik, akreditasi jurnal ilmiah, indeksasi jurnal. Berbekal upaya dan kemauan yang sungguh-sungguh Berkala Ilmu Perpustakaan dan Informasi berhasil lolos meraih status akreditasi sebagai jurnal bidang ilmu perpustakaan terakreditasi yang pertama kali di Indonesia.

Penelitian pertama meneliti tentang indeksasi jurnal ilmiah pertanian yang terdapat pada DOAJ dengan melihat jenis penerbit, biaya penerbitan, tahun pertama terbit pada DOAJ, dan proses review. Penelitian kedua lebih berfokus kepada bagaimana DOAJ memperluas dan memperbarui kriteria dan proses evaluasi jurnal yang ingin memiliki indeksasi DOAJ. Dimana dengan diberlakukannya sistem ini banyak beberapa jurnal yang kehilangan DOAJ sebagai 
lembaga pengindek. Penelitian ketiga mendeskripsikan bagaimana sebaiknya usaha yang harus dilakukan pengelola jurnal khususnya pengelola jurnal berkala perpustakaan untuk mencapai jurnal ilmiah terakreditasi nasional. Dari ketiga tinjauan pustaka di atas penelitian terkait perkembangan indeksasi atau lembaga pengindeks pada jurnal ilmiah belum pernah dilakukan. Lembaga pengindeks akan membantu mempromosikan jurnal yang diindeksasikan kepada publik, artinya indeksasi bertujuan mendiseminasikan metadata artikel terbitan berkala ilmiah sehingga lebih mudah ditemukan dengan cara mencatatkan metadata tersebut di lembaga pengindeks. Apabila jurnal telah terindeks di banyak database, maka secara tidak langsung akan memudahkan sitasi secara global. Dengan meningkatnya jumlah sitasi jurnal, maka reputasinya otomatis akan meningkat/naik (Junandi, 2018).

Jika dilihat dari akreditasi jurnal yang ada, maka dari 29 (dua puluh sembilan), sepuluh jurnal sudah terakreditasi oleh Akreditasi Jurnal Nasional atau disebut juga dengan Arjuna (Pengembangan, Riset, and Tinggi n.d.) dan belum semua jurnal memiliki pengindeks baik itu indeksasi dalam tingkat tinggi, sedang dan rendah, selain itu belum pernah ada kajian yang menganalisa seberapa banyak jenis indeksasi yang dimilki dan jurnal mana saja yang telah memiliki indeksasi. Tujuan dilakukannya penelitian ini yaitu untuk mendapatkan gambaran lembaga pengindeks yang dimiliki oleh jurnal-jurnal yang ada di Unilak baik itu jumlah lembaga pengindeks, maupun reputasi lembaga pengindek yang dimiliki. Dengan harapan pengelola jurnal tidak hanya dapat meningkatkan jumlah lembaga pengindeks namun termotivasi memiliki lembaga pengindeks bereputasi tinggi. Berdasarkan hasil pengamatan melalui website Journal Unilak terdapat 16 jurnal yang sudah memiliki indeksasi sehingga dalam penelitian kali ini peneliti hanya memfokuskan pada 16 jurnal tersebut.

\section{METODE PENELITIAN}

Metode yang digunakan dalam penelitian ini adalah metode deskriptif kuantitatif melalui pendekatan kepustakaan. Kepustakaan yang dimaksud yaitu dengan cara melakukan penelusuran secara online. Penelusuruan dilakukan dengan cara mengakses langsung jurnal Unilak melalui URL https://journal.unilak.ac.id/ kemudian mendata satu demi satu setiap jurnal yang ada melalui masing-masing URL jurnal, sedangkan hasil penelusuran ini akan disajikan dan dideskripsikan dalam bentuk tabel, angka dan diagram. Berikut alamat URL online Jurnal System (OJS) Unilak:

Tabel 2

Daftar URL Jurnal Unilak pada Online Jurnal Sistem (OJS)

\begin{tabular}{lll}
\hline No & \multicolumn{1}{c}{ Nama Jurnal } & \multicolumn{1}{c}{ URL } \\
\hline 1 & Jurnal Teknik & journal.unilak.ac.id/index.php/teknik \\
2 & Dinamisia & https://journal.unilak.ac.id/index.php/dinamisia \\
3 & PAUD Lectura & http://journal.unilak.ac.id/index.php/paud-lectura/ \\
4 & Bio Lectura & journal.unilak.ac.id/index.php/BL \\
5 & Lectura: Jurnal Pendidikan & http://journal.unilak.ac.id/index.php/lectura \\
6 & ELT- Lectura & http://journal.unilak.ac.id/index.php/ELT-Lectura \\
7 & Wahana Foresta: Jurnal Kehutanan & http://journal.unilak.ac.id/index.php/forestra \\
8 & Jurnal Niara & https://journal.unilak.ac.id/index.php/nia \\
9 & Jurnal Hukum Respublica & http://journal.unilak.ac.id/index.php/Respublica \\
10 & Jurnal Ilmiah Pertanian & http://journal.unilak.ac.id/index.php/jip \\
11 & Jurnal Agribisnis & journal.unilak.ac.id/index.php/agr \\
12 & Digital Zone & https://journal.unilak.ac.id/index.php/dz/ \\
13 & Jurnal Ilmiah Ekonomi dan Bisnis & http://journal.unilak.ac.id/index.php/JIEB \\
14 & Jurnal Ilmu Budaya & journal.unilak.ac.id/index.php/jib \\
15 & Jurnal Pustaka Budaya & http://journal.unilak.ac.id/index.php/pb \\
16 & SIKLUS: Jurnal Teknik Sipil & journal.unilak.ac.id/index.php/SIKLUS \\
\hline
\end{tabular}

Sumber: https://journal.unilak.ac.id/ 


\section{HASIL DAN PEMBAHASAN}

Pertumbuhan jurnal di lingkungan Universitas Lancang Kuning dimulai tahun 2004, dan hingga saat ini jurnal ilmiah di Unilak berjumlah 29 jurnal, dari 29 jurnal tersebut 16 jurnal telah memiliki indeksasi dan 13 jurnal belum memiliki indeksasi. Di Indonesia, indeksasi yang sering digunakan dalam acuan penelitian seorang dosen atau peneliti adalah scopus, google scholar, dan sinta dikti (Zaenuri, Suhada, \& Widaningsih, 2019). Berikut gambaran 29 Jurnal Unilak dalam tabel 3.

Tabel 3

Jumlah Indeksasi Jurnal di Lingkungan Unilak

\begin{tabular}{llc}
\hline No & Ket Indeks & Jumlah \\
\hline 1 & Terindeks & 16 \\
2 & Belum terindeks & 13 \\
\hline & Total & 29 \\
\hline
\end{tabular}

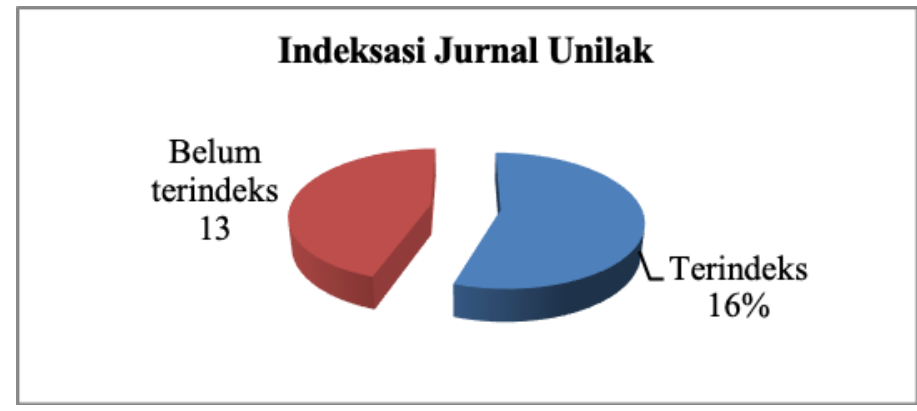

Gambar 1

Diagram Indeksasi Jurnal Unilak

Indeksasi jurnal di lingkungan Unilak dapat dilihat pada gambar 1. Terlihat bahwa lebih dari setengahnya jurnal dilingkungan Unilak telah memiliki indeksasi yaitu 16 jurnal sedangkan 13 jurnal belum memiliki indeksasi atau lembaga pengindeks. Adapun gambaran 16 (enam belas) jurnal yang memiliki indeksasi dapat dilihat pada tabel 4.

Tabel 4

Jurnal yang Telah Memiliki Indeksasi

\begin{tabular}{llc}
\hline No & \multicolumn{1}{c}{ Nama Jurnal } & $\begin{array}{c}\text { Tahun } \\
\text { Pertama Terbit }\end{array}$ \\
\hline 1 & Jurnal Teknik & 2007 \\
2 & Dinamisia: Jurnal Pengabdian Kepada Masyarakat & 2017 \\
3 & PAUD Lectura: Jurnal Pendidikan Anak Usia Dini & 2017 \\
4 & Bio Lectura & 2014 \\
5 & Lectura: Jurnal Pendidikan & 2014 \\
6 & ELT- Lectura & 2014 \\
7 & Wahana Foresta: Jurnal Kehutanan & 2015 \\
8 & Jurnal Niara & 2016 \\
9 & Jurnal Hukum Respublica & 2016 \\
10 & Jurnal Ilmiah Pertanian & 2005 \\
11 & Jurnal Agribisnis & 2015 \\
12 & Digital Zone & 2015 \\
13 & Jurnal Ilmiah Ekonomi dan Bisnis & 2015 \\
14 & Jurnal Ilmu Budaya & 2004 \\
15 & Jurnal Pustaka Budaya & 2014 \\
16 & SIKLUS: Jurnal Teknik Sipil & 2015 \\
\hline
\end{tabular}


Tabel 4 menunjukkan nama-nama enam belas jurnal yang telah terindeks pada lembaga pengindeks. Keeman belas jurnal tersebut memiliki tahun terbit yang berbeda-beda. Jurnal Ilmu Budaya (2004), Jurnal Ilmiah Pertanian (2005), Jurnal Teknik (2007), Bio Lectura, Lectura: Jurnal Pendidikan, ELT-Lectura, Jurnal Pustaka Budaya (2014), Jurnal Agribisnis, Digital Zone, Jurnal Ilmiah Ekonomi dan Bisnis, SIKLUS: Jurnal Teknik Sipil (2015), Jurnal Niara dan Jurnal Hukum Respublica (2016, dan Dinamisia: Jurnal Pengabdian Kepada Masyarakat, PAUD Lectura: Jurnal Pendidikan Anak Usia Dini (2017).

Tabel 5

Jenis Indeksasi Jurnal di Unilak

\begin{tabular}{|c|c|c|}
\hline No & $\begin{array}{r}\text { Jenis Indeksasi } \\
\end{array}$ & Jumlah Indeks \\
\hline 1 & Academic Resorcer Index & 1 \\
\hline 2 & Bielefels Academic Search Engine (BASE) & 9 \\
\hline 3 & CiteFactor (Academic Scientific Journal) & 1 \\
\hline 4 & CITY University of London & 1 \\
\hline 5 & Copac Jics & 4 \\
\hline 6 & Crossref & 16 \\
\hline 7 & Dimension & 5 \\
\hline 8 & Directory of Open Accses Journal (DOAJ) & 7 \\
\hline 9 & Discover MWU University Libraries & 1 \\
\hline 10 & EBSCO & 4 \\
\hline 11 & Electronische Zeitcritenbibliothek (CZ3) & 1 \\
\hline 12 & Garuda & 11 \\
\hline 13 & Google Scholar & 16 \\
\hline 14 & Hardvard Library & 6 \\
\hline 15 & Indek Corpenicus & 1 \\
\hline 16 & Indonesia One Search & 2 \\
\hline 17 & Ingenta & 1 \\
\hline 18 & Indonesia Publication Index (IPI) & 1 \\
\hline 19 & Indoensia Scientific Journal Database (ISJD) & 2 \\
\hline 20 & Journal TOCs & 2 \\
\hline 21 & LIPI & 5 \\
\hline 22 & Neliti & 2 \\
\hline 23 & Nelson Mandela & 2 \\
\hline 24 & OCLC WorldCat & 10 \\
\hline 25 & OpenAIRE & 1 \\
\hline 26 & Directory of Open Access Scholary Resources (ROAD) & 6 \\
\hline 27 & Science of Technology Index (Sinta) & 8 \\
\hline 28 & Sherpa/ Romeo & 1 \\
\hline 29 & Standford Libraries & 1 \\
\hline 30 & Solo (Search Oxford Libraries Online) & 1 \\
\hline 31 & The University of Hongkong Libraries & 1 \\
\hline 33 & The University of Sheffield & 3 \\
\hline 33 & University of Oxford & 3 \\
\hline 34 & University Of Saskatchewan & 1 \\
\hline 35 & University Leiden & 1 \\
\hline 36 & UNSW Sidney & 2 \\
\hline 37 & Vancover Public Library & 2 \\
\hline \multirow[t]{2}{*}{38} & Vrije University Brussel & 1 \\
\hline & Total & 143 \\
\hline
\end{tabular}

Pada table 5 tampak Jurnal Universitas Lancang Kuning terindeks pada 38 (tiga puluh delapan) jenis lembaga pengindeks. Lembaga pengindeks atau indeksasi jurnal yang dimiliki 
terdiri dari dua tingkat yaitu tingkat rendah dan sedang, artinya jurnal Unilak belum memiliki indeksasi dengan tingkat tinggi seperti Web of Science (Thomson Reuters) dan Scopus (Elsevier). Lembaga pengindeks bereputasi tinggi mempunyai ciri-ciri, memiliki berbagai bidang ilmu, mempunyai database terbesar di dunia, mempunyai perangkat untuk analisis sitasi dan pemeringkatan jurnal, menjadi acuan dalam pemeringkatan perguruan tinggi tingkat dunia, serta relative sangat selektif untuk terindeks. Sedangkan lembaga pengindeks dengan reputasi sedang memiliki ciri dapat meliputi dan menjadi acuan pengindeksan di bidang ilmu tertentu, mempunyai database yang cukup besar, tidak perlu memiliki perangkat analisis sitasi dan pemeringkatan jurnal, relatif lebih selektif untuk bisa terindeks. (Lukman).

Adapun lembaga pengindeks jurnal Unilak yaitu, Academic Resorcer Index, Bielefels Academic Search Engine (BASE), CiteFactor (Academic Scientific Journal), CITY University of London, Collective Goods Research \& Explorer (CORE), Copac Jics, Crossref, Dimension, Directory of Open Access Journal (DOAJ), Discover MWU University Libraries, EBSCO, Electronische Zeitcritenbibliothek (CZ3), Garuda, Google Scholar, Hardvard Library, Indek Corpenicus, Indonesia One Search, Ingenta, Indonesian Publication Index (IPI), Indonesian Scientific Journal Database (ISJD), Journal TOCs, Leiden University Libraries, LIPI, Neliti, Nelson Mandela, OCLC WorldCat, ORCID, OpenAIRE, Directory of Open Access Scholary Resources (ROAD), Science of Technology Index (Sinta), Sherpa/ Romeo, Standford Libraries, Standford Unversity, Search Oxford Libraries Online (Solo), The University of Hongkong Libraries, The University of Sheffield, University of Oxford, University Of Saskatchewan, University Leiden, University Library, University Public, UNSW Sidney, Vancover Public Library, Vrije University Brussel, dan Western Technologi.

Sehingga dari 38 jenis pegindeks dengan 143 indeksasi yang tersebar di 16 jurnal, terdapat peringkat lima teratas pengindeks yang dimiliki pertama, Crossref dan Google Scholar yaitu 16 jurnal atau 11, 18,83\%. Kedua ada pada indeksasi Garuda yaitu 11 jurnal atau 7,69\%, ketiga indeksasi OCLC WorldCat sebanyak 10 jurnal atau dengan peresentase 6,99 \%, keempat indeksasi Bielefels Academic Search Engine (BASE) yaitu 9 jurnal 6,29 \% dan yang kelima ada pada Science and Technology Index (Sinta) dengan jumlah 8 jurnal (5, 59\%). Sedangkan jumlah indeksasi yang digunakan setiap jurnal bebeda-berbeda, adapun gambaran jumlah indeksasi pada setiap jurnal dapat dilihat pada tabel 6 berikut.

Tabel 6

Jumlah Indeksasi Setiap Jurnal

\begin{tabular}{llc}
\hline No & \multicolumn{1}{c}{ Nama Jurnal } & Jumlah \\
\hline 1 & Jurnal Teknik & 4 \\
2 & Dinamisia: Jurnal Pengabdian Kepada Masyarakat & 13 \\
3 & PAUD Lectura: Jurnal Pendidikan Anak Usia Dini & 7 \\
4 & Bio Lectura & 4 \\
5 & Lectura: Jurnal Pendidikan & 21 \\
6 & ELT- Lectura & 7 \\
7 & Wahana Foresta: Jurnal Kehutanan & 6 \\
8 & Jurnal Niara & 17 \\
9 & Jurnal Hukum Respublica & 5 \\
10 & Jurnal Ilmiah Pertanian & 3 \\
11 & Jurnal Agribisnis & 12 \\
12 & Digital Zone: Jurnal Teknologi Informasi dan Komunikasi & 11 \\
13 & Jurnal Ilmiah Ekonomi dan Bisnis & 3 \\
14 & Jurnal Ilmu Budaya & 2 \\
15 & Jurnal Pustaka Budaya & 19 \\
16 & SIKLUS: Jurnal Teknik Sipil & 9 \\
\hline & & 143 \\
\hline
\end{tabular}


Tabel 6 menunjukkan gambaran jumlah indeksasi yang dimiliki oleh setiap jurnal, Jurnal yang paling banyak memiliki indeksasi, pertama Jurnal Lectura: Jurnal Pendidikan dengan jumlah 21 pengindeks, kedua Pustaka Budaya dengan jumlah 19 pegindeks, ketiga Jurnal Niara dengan jumlah 17 pengindeks , keempat ada pada jurnal Dinamisia: Jurnal Pengabdian Kepada Masyarakat memiliki 13 pengindeks, kelima Jurnal Agribisnis memiliki 12 pengindeks, keenam Digital Zone: Jurnal Technologi Informasi dan Komunikasi memiliki 11 pengindeks, ketujuh SIKLUS: Jurnal Teknik Sipil memiliki 9 pengindeks, kedelapan ada pada jurnal PAUD Lectura: Jurnal Pendidikan Anak Usia Dini dan ELT-Lectura yang sama-sama memiliki 7 pengindeks, kesembilan Jurnal Wahana Foresta memiliki 6 pengindeks, kesepuluh Jurnal Hukum Respublika yang memiliki 5 pengindeks, kesebelas ada pada jurnal Teknik dan BIO Lectura yang mimiliki jumlah pengindek yang sama yaitu 4 pengindek, dua belas ada pada jurnal Ilmiah Pertanian dan Jurnal Ilmiah ekonomi dan Bisnis memiliki 3 pengindeks, selanjutnya ketiga belas ada pada Jurnal Ilmu Budaya yang memiliki 2 pengindek.

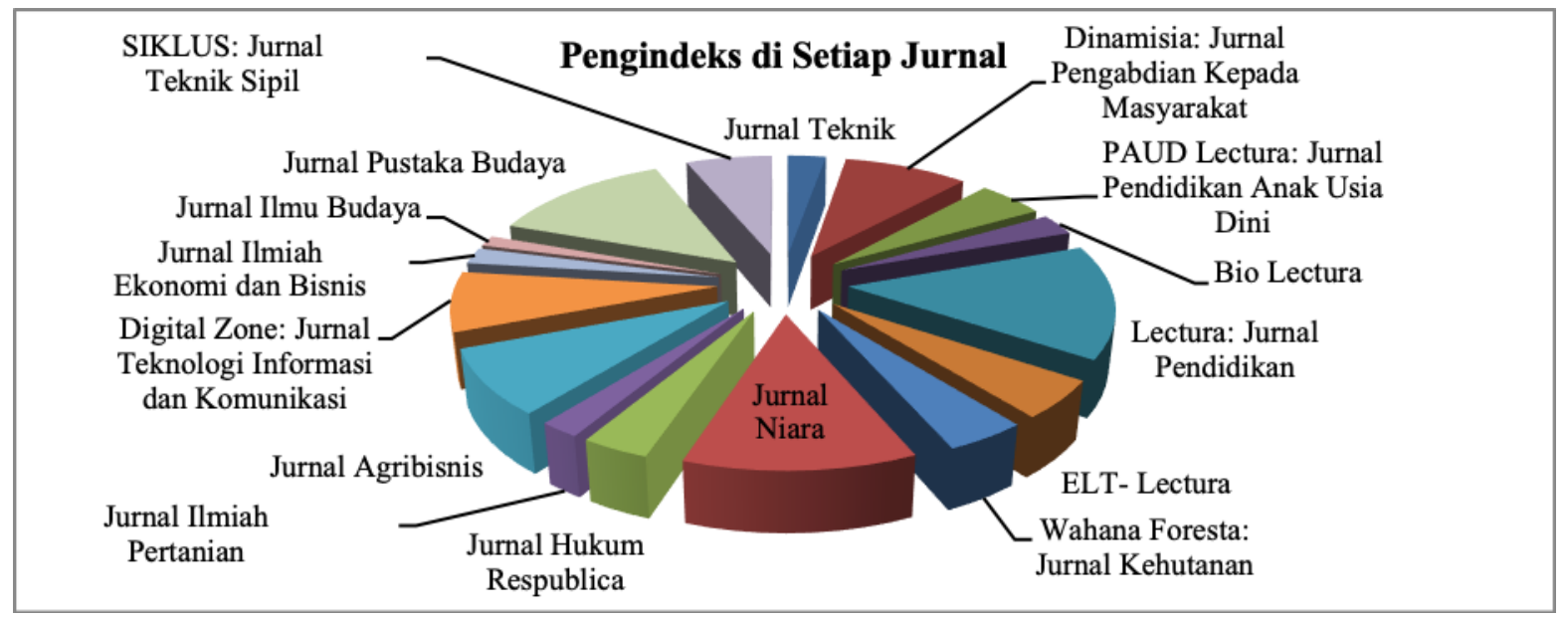

Gambar 2

Pengindeks di Setiap Jurnal

Hasil distribusi menunjukkan bahwa jurnal-jurnal Unilak yang sudah terindeks pada lembaga pengindeks. Terdapat 38 jenis lembaga pengindeks dari 143 lembaga pengindeks, jika dilihat dari reputasi lembaga pengindeks tersebut jurnal Unilak belum memiliki lembaga pengindeks dengan reputasi tinggi dan minim lembaga pengindeks dengan reputasi sedang. Ada beberapa faktor yang menyebabkan jurnal Unilak belum terindeks oleh lembaga pengindeks bereputasi sedang dan tinggi diantaranya adalah masih rendahnya kualitas artikel, manageman dan pengelolaan jurnal yang belum sesuai dengan standar internasional, komposisi penyunting belum berskala internasional, pengelolaan e-journal belum menggunakan OJS, rendahnya sitasi jurnal ilmiah dan minimnya informasi indeksasi. Melihat kondisi ini perlu adanya kebijakan yang mengatur terkait pengelolaan jurnal yang dituangkan dalam bentuk SOP dan buku panduan pengelolaan jurnal yang sesuai dengan standar Dikti.

\section{SIMPULAN}

Dapat disimpulkan bahwa Universitas Lancang Kuning memiliki 29 Jurnal ilmiah, dari 29 jurnal yang ada terdapat 16 jurnal yang telah memiliki lembaga pengindeks dengan jumlah yang beragam. Adapun jurnal tersebut Jurnal Lectura: Jurnal Pendidikan, Pustaka Budaya, Jurnal Niara, Dinamisia: Jurnal Pengabdian Kepada Masyarakat, Jurnal Agribisnis, Digital Zone: Jurnal Technologi Informasi dan Komunikasi, SIKLUS: Jurnal Teknik Sipil, PAUD Lectura: Jurnal Pendidikan Anak Usia Dini, ELT-Lectura, Jurnal Wahana Foresta, Jurnal Hukum Respublika, 
Jurnal Teknik, BIO Lectura, Jurnal Ilmiah Pertanian, Jurnal Ilmiah Ekonomi dan Bisnis, dan Jurnal Ilmu Budaya. Untuk jenis lembaga pengindeks yang dimiliki terdiri dari lembaga pengindeks sedang dan rendah, sedangkan lima lembaga pengindeks terbanyak yang dimiliki pertama Crossref dan Google Scholar, kedua ada pada pengindeks Garuda, Garuda merupakan portal yang memberikan banyak keuntungan, karya ilmiah lebih bermutu, dan terhindar dari dauplikasi penelitian (Khayatun \& Rahayu, 2010), ketiga pengindeks OCLC WorldCat, keempat pengindeks Bielefels Academic Search Engine (BASE) dan yang kelima ada pada pengindeks Science and Technology Index (Sinta).

Agar jurnal di Unilak memiliki lembaga pengindeks bereputasi tinggi dan meningkatkan jumlah lembaga pengindeks dengan reputasi sedang yaitu perlu adanya sumber daya manusia (pengelola jurnal) yang fokus dalam mengelola jurnal serta didukung dengan kebijakan dari institusi sehingga pengelola jurnal dapat meningkatkan pertama kualitas publikasi jurnal seperti ruang lingkup, gaya selingkung, dan manajemen referensi. Kedua manajemen jurnal seperti kelembagaan, infrastruktur, kinerja jurnal dan pendanaan atau komitmen.

\section{DAFTAR PUSTAKA}

Andrea Marchitelli dan Galimberti, P. (2017). Improvment of Editorial Quality of Journals Indexed in DOAJ: a data analysis. JLIS.it, 1-21.

Hariyanto, E. (2016). Qua Vadis The Quality Of Online Scientific Journal Publishing In State Islamic Religious University (PTKIN). Khizanah Al-Hikmah, 76-90.

Hs, L. (2009). Kamus Kepustakawaan Indonesia: Kamus Lengkap Istilah-Istilah Dunia Pustala dan Perpustakaan yang Ditulis Lengkap Oleh Pustakawan Senior. Yogyakarta: Pustaka Book Publisher.

Indriyanti, Y. D. (2010). Open Journal System (OJS) Untuk Mengelola Publikasi Ilmiah. Jurnal Pustakawan Indonesia, 10(2), 38-46.

Jamaluddin. (2015). Mengenal Elektronik Jurnal Dan Manfaatnya Bagi Pengembangan Karier Pustakawan. JUPITER, 40.

Janet Stevenson dan Collin, P. (2006). Dictionary of Information and Library Management. London: A \& C Black.

Junandi, S. (2018). Pengelolaan Jurnal Elektronik Bidang Perpustakaan Menuju Jurnal Terakreditasi. PUSTABILITA: Journal of Library and Information Science, 119-136.

Kementerian Riset, T. D. (2017). Sinta2. Retrieved Agustus Rabu, 2019, from http://sinta2.ristekdikti.go.id: http://sinta2.ristekdikti.go.id/journals?search=1\&pubid=2896

Khayatun, \& Rahayu, S. (2010). Peran Perpustakaan IPB Sebagai Kontributor Portal Garuda (Garba Rujukan Digital). Jurnal Pustakawan Indonesia, 10(2), 11-17.

Lukman. (n.d.). Kebijakan dan Strategi Pengelolaan Jurnal Elektronik. (Rapat Koordinasi Pengelola Jurnal Ilmiah di Lingkungan BPP Kemendagri dan Pemerintah Daerah, Universitas, serta Kementerian/Lembaga) Aula BPP Kementerian Dalam Negeri. Jakarta, DKI Jakarta, Indonesia: PDI LIPI. 
Maxmanroe.com, 2. (2019). maxmanroe.com. Retrieved Agustus Rabu, 2019, from https://www.maxmanroe.com:

https://www.maxmanroe.com/vid/finansial/akuntansi/pengertian-jurnal-umum.html

Nashihudin, W., \& Rahayu, R. N. (2010). Aksesibilitas informasi Ilmiah Science Dicrect Pustaka Ristek di Lingkungan Ristek dan LPNK. Jurnal Pustakawan Indonesia, 12(2), 1-9.

Rahmawati. (2018). Analisis Indeksasi Jurnal Ilmiah Bidang Pertanian Indonesia di DOAJ. Rahmawati, 36-41.

Sahrudin, U. (2019). Peran Pustakawan Dalam Pengelolaan dan Penerbitan Jurnal Ilmiah (Role of Library in Management and Publishing Scientific Journals). KANDAGA, 1(1), 10-20.

Suryoputro, G., Riyadi, S., \& Sya'ban, A. (2012). Menulis Artikel Untuk Jurnal Ilmiah. Jakarta: Uhamka Press.

Wicaksono, H. (2018). Pemanfaatan E-Journal oleh Mahasiswa pada Perpustakaan Perguruan Tinggi di Jakarta. Lentera Pustaka: Jurnal Kajian Ilmu Perpustakaan , Informasi dan Kearsipan, 4(2), 67-78.

Widodo, Amini, M., Nuringtyas, T. N., Fauzi, S., Handayani, T., Istiana, P., et al. (2017). Panduan Indeksasi Manajemen Referensi, dan AKreditasi Jurnal. Yogyakarta: Gajah Mada University Press.

Zaenuri, M., Suhada, \& Widaningsih, I. (2019). Kajian Publikasi Ilmiah Dosen Fakultas Ekonomi dan Bisnis Universitas Padjajaran Dalam Indeks Scopus, Google Scolar, dan SINTA (Science and Technology Index). KANDAGA, 1(1), 8-17. 